\title{
ТІМЕНИК ЗИНОВІЙ,
}

кандидат філософських наук, дочент кафедри історії України та етнокомунікації,

Національний університет "Львівська політехніка", м. Львів

\section{ІНТЕРПРЕТАЦІЯ ЯЗИЧНИЦЬКОГО У ФІЛОСОФСЬКО-РЕЛІГІЙНИХ ІДЕЯХ (ЗІ СПАДЩИНИ УКРАЇНСЬКИХ МИСЛИТЕЛІВ 70-Х рР. ХІХ - 60-Х рр. ХХ $\mathrm{cm}.)^{1}$ : МЕТОДОЛОГІЧНІ РЕФЛЕКСІї}

На підставі спадщини українських філософів зазначеного періоду роль язичницького висвітлено в контексті ідеї Бога в структурі людини, світобудови та ідей одкровення, преображення (духовного оновлення). Особливістю методологічних розмислів є увага до різноманітних проявів темпоритміки. Автор обґрунтовує об'єктивний взаємозв'язок та гармонійність цих ідей.

Ключові слова: "божественна діалектика"; "містичний розум"; "одкровенознавство"; "релігійна логіка"; темпоритміка.

Постановка проблеми та стан її дослідження. Глобалізація українського світу спонукує до системного осмислення комплексу таких тем, через опрацювання котрих уможливлено цілеспрямовано відтворювати світоглядну специфріку наших пращурів-язичників (на часі - реальне усвідомлення непересічного значення їхнього набутку з погляду запропонованої теми). Усвідомлювати назване - означає поглиблювати теоретико-методологічні засади. Найперше - про сам феномен спільності деяких світоглядних рис наших предків і сучасних українців, зокрема, щодо пошанування природи й олюднення всього Божого світу чи коли мовити про феномен багатосотлітнього побутування окремих дохристиянських понять у нашому богослов'ї. У межах українського релігієзнавчого дискурсу осмислювати назване означає передусім долати свої внутрішні стереотипи, котрі виявляють себе в тенденції до так званої "захристиянізованості". Ще дві проблеми. Перша: з огляду на більшу повноту й усебічність досліджень відповідних тем доцільно вводити нові терміни, бо під час аналізу відчувається їх недостатність. Зосібна, коли мовити про "кількапроцесуальне одночасся", "овірування", "одкровенознавство" (останнє поняття - на перспективу, коли з цілковитою долею ймовірності може утвердитися згодом однойменна галузь знання) ${ }^{2}$. Друга проблема - у назрілій потребі давати нове життя тим поняттям, котрі десятиліттями не могли використовуватись серед обставин тоталітарного режиму в СРСР. Це, зокрема: "містичний розум" [4, с. 327-328], "божественна діалектика" [1, с. 315], "релігійна логіка" [2, с. 604], "богослов'я пантеїзму" 3 та ін. Їх залучення сприятиме фор-

\footnotetext{
1 У статті часові рамки осмисленого матеріалу обмежено 60ма роками XX ст. з огляду на "Основи християнської філософрії" В. Зіньківського, перше двотомне видання яких опубліковано було у Франкфурті-на-Майні протягом 1961-1964рр. Сентенції цього автора використано з видання 1997 року. ${ }^{2}$ Названі поняття $€$ авторськими. Про розкриття їх змісту див.: журнал "Схід". - 2015. - № 4. - Травень-червень. - С. 79. ${ }^{3}$ Див.: Зеньковский В., прот. Об участии Бога в жизни мира / В. Зеньковский, прот. // Православная мысль. Труды Право-
}

муванню нових відношень, моделей (за безпосередньої чи супровідної участі відповідних методів, принципів). Створиться реальна ситуація для глибшого вивчення структури й функцій (між)релігійних 4 комунікацій, міждисциплінарного простору, у середовищі яких, через взаємообумовленість яких і виражається передусім фрілософрія релігії з її ідеями.

Розмірковуючи про стан дослідження, є підстави стверджувати: матеріалів, які безпосередньо стосувалися б цієї статті, не виявлено. У низці публікацій наявні розмисли, що дотично чи сегментно стосуються запропонованої теми. Так, зокрема, Д. Марцінковська з погляду кредології зосереджується на типологічних зіставленнях щодо "...віри в Бога, як джерела релігії..." [8, с. 99]. Торкаючись феноменологічного виміру запропонованої проблематики, авторка, одначе, не мала наміру осмислювати віру са́ме у філософсько-релігійному сенсі, хоча їі теза про віру своїм універсальним спрямуванням опосередковано $є$ дотичною до обміркованих тут ідей, оскільки таке духовне поняття найперше стає гармонізуючим чинником у (між)релігійних комунікаціях. Стосовно І. Печеранського, то в його статті латентно прочитуються вияви історичної пам'яті про язичницько-християнський простір, а відтак - і про можливе утвердження ідеї істинності й повноти (між)релігійних комунікацій (але - залежно від "'укоріненості" національної традиції ... у віковічній мудрості предків, яка оповита тенденцією до сакралізації минулого" [10, с. 286]). Звідси випливає, що така сакралізація безпосередньо залежить принаймні від двох форм виражених чинників - укоріненості й оповитості - а вони (ці форми) своєю чергою свідчать про вплив елементів синтезування у названім комплексі процесів на різних етапах розвитку конкретної ідеї. У руслі методологічних

славного Богословского Института в Париже. - Париж : YMCAPRESS, 1957. - Вып. VI. - С. 82.

4 Про обґрунтованість написання префікса між у круглих дужках див.: ж. "Схід". - 2016. - № 1 (141) - Січень-лютий. - С. 93.

5 Курсив І. Печеранського. 
рефлексій слушною видається сентенція С. Преображенського про "брак продуктивних теоретичних моделей..." під час "...висвітлення національно-релігійного життя за умов світоглядного плюралізму..." [11, с. 1-2]. Однак, зазначимо, що повновартісно фрормуватись названі моделі зможуть за умов належного термінотворення, яке повинно набути системного спрямування.

Мета дослідження полягає в тім, щоби на підставі спадщини українських мислителів окресленого періоду з'ясувати, якою мірою закономірними є їхні розмисли стосовно феномену язичництва під час фрункціонування фрілософсько-релігійних ідей. Маємо на увазі: ідею Бога в структурі людини, світобудови і з погляду системи Його наймень, а також - ідею одкровення, преображення (духовного оновлення).

Виклад основного матеріалу. Передусім необхідно ствердити: функціонування названих ідей не $є$ самозамкнутим - у своєму вираженні вони сегментують зі спонтанною ситуативністю, опиняючись інколи і в стані дотичності. Відтак їх взаємодія уреальнюється через складні, неоднозначні темпоритмічні вираження методів, принципів, відношень. До комплексу процесів причетні як складові ідей, так і сама сукупність їх внутрішньоструктурних рис із потенційною здатністю до гармонізації. Необхідність вивчення таких станів обґрунтовували тогочасні мислителі, часто наголошуючи не тільки на їхній історико-духовній значущості, а й водночас прагнучи доречно використовувати відповідні методологічні чинники. Тому закономірною стає застереження В. В. Зеньковського від ковзання по "периферії проблем" [6, с. 136] - як вияву псевдонауковості.

У різножанровій спадщині українських мислителів виклад язичницького поданий переважно непроявно (а то й - латентно) через цензуру чи певні недомовленості, зважаючи на одночасні вияви переважно двох форм мислення - фрілософрсько-релігійного та християнсько-богословського. Назване спонукує специфічно трактувати тексти, зокрема, застосовуючи герменевтичний метод.

Ідея Бога (Божества) у структурі людини, світобудови і з погляду системи Його наймень. Обміркована ідея найперше спонукує з'ясувати, що поняття про Того, Хто Найвищий могло усталюватись тільки поетапно. Для цього в межах компаративного методу українські мислителі одночасно використовували принцип поступовості-послідовності із супровідно-ситуативним імпліцитним виявом відношення "Бог-людинаБог". Якраз таке комплексне поєднання методологічних чинників давало їм підстави одночасно формувати контекст психофізичних і моральних станів. Зосібна, Сильвестр Ґоґоцький розмірковував: "У людині першим ступенем богоусвідомлення, котрий був приставлений до її власних сил, може бути невиразне уявлення Божества у вигляді однієї безкінечності і такої могутності, що підсвідомо діє: ні вища, наймогутніша сутність, ні особисте єство людини не мають ще морального значення. Чим далі посувається [вперед] внутрішній розвиток людини, тим видиміше виникає усвідомлення моральних властивостей божественної сутності щодо Божества" [4, с. 278].

Проглядається тут і закономірність своєрідної "ієрархізації" комплексних станів і визнається неминучість ступеневого сприйняття Бога (Божества). Відтворюючи назване, дослідник у поетапному сприйнятті Того, Хто Найвищий мимоволі уконтекстовує такі стани у (між)релігійні комунікації, водночас не акцентуючи на вирішальності тієї чи тієї віровизнавчої системи - язичниць- кої чи християнської. Також латентно прочитується думка: відношення "Бог-людина-Бог" має складну історію формування. Адже треба зважати на те, що людина - як другий елемент цього відношення - органічно концентрує в собі свій внутрішній світ, його наслідкові прояви. За виниклих обставин названі стани уреальнюються в міждисциплінарнім просторі передусім - у сферах психофрізичній, моральній. Таким чином, через метод індивідуалізації можна простежити, як поетапно людина сприймала Божество крізь прожиті епохи. Водночас С. Ґоґоцький імпліцитно стверджує: без зафункціонування елементів міждисциплінарного простору назване сприйняття гармонійно не усталилося б.

Із супровідною одночасністю (поруч із функціональним) виявляє себе й герменевтичний метод. Зокрема, проглядається таке в Сергія Булгакова: коли через принцип поступовості-послідовності максимально універсалізовано смислове значення конкретного поняття і разом із тим - уконтекстовано в своєрідний "каскад" взаємообумовлених процесів, станів. Він розмірковував: "Поняття "божество", "бог" уживаємо наразі у найневизначенішому значенні, яке охоплює різні релігії... На такій стадії для трансцендентальної характеристики однаково, чи поклоняється людина дерев'яній колоді, пов'язуючи свою віру в божественне, чи ж [-] триіпостасному Богові: сутнісною ознакою, що усталює природу релігії, є об'єктивний характер такого поклоніння, пов'язаний із чуттям трансцендентності ... божества" [2, с. 594].

Сприйняття Того, Хто Найвищий утрактуванні С. Булгакова фактично ввібрало і язичницьку позицію (через поклоніння "дерев'яному чурбану"). Між тим принцип поетапності-послідовності використано, щоб зазначити: для акцентації непроявно вираженої думки мусили існувати періоди в духовнім розвитку людини, коли пріоритетним ставала сама увага до культу поклоніння всеохопної універсальної традиції, що збереглася крізь епохи. Отже, у структурах названої традиції можна розмірковувати хіба що про її особливості, різновиди. Супровідно, за виниклої ситуації, дослідник імпліцитно фактично визнає за язичництвом статус релігії, не натякаючи навіть, що цій духовній системі може бути притаманний статус лишень дохристиянського вірування.

Окрім того, через принцип додатковості С. Булгаков латентно стверджує: існує можливість гармонізувати дихотомію "філософрія релігії/теологія" хоча б з огляду на те, що чуття трансцендентності Божества (у будьякому іпостасному чи неіпостасному Його вираженні) виявлялось завжди. Підтвердженням $є$ об'єктивна дія споконвічного відношення "Бог-людина-Бог". Інакше несприйняття цього суперечило б самій природі людини як творінню Божому, у духовнім просторі якої стан трансцендентності-іманентності так чи так виявляє себе за будь-якої епохи - без огляду на віровизнавчу систему. Тому на шляху до утвердження обміркованої ідеї в таких мисленнєвих ситуаціях принцип додатковості через зв'язок з іншими методологічними чинниками здатен гармонізувати несумісні когнітивні поняття. Цього разу - коли мовити про культ поклоніння дерев'яному чурбану чи про поклоніння Триіпостасному Богові. Відповідно, названий принцип дає змогу усвідомлено долати застереотипізованість, а відтак - і ймовірний когнітивний дискомфорт щодо емоційного сприйняття названих поклонінь.

3 погляду компаративного методу в дещо іншому ключі - позиція Василя Зеньковського. Феноменологізуючи спроможність "каскаду" процесів (з увагою до 
первісного сприйняття Божества, до ймовірного структурування такого сприйняття з погляду філософської концепції часу), він стверджував, що існує "...безпосередня Богосвідомість, живе й непереборне, першопочаткове звернення душі до Бога, ...живий зв'язок з Ним. Тут ще нема ніяких "ідей", чи "вірувань", чи "почуттів", тобто всього того, що увійде згодом у феноменологію віри... Таке знання Бога дає світлоносна сила, що ізходить із [Нього] в нашу душу" [7, с. 44].

Контекстуальне утвердження обміркованої ідеї формується в дослідника найперше засобами феноменологічного методу. Автор "Основ християнської фрілософфії" прагне осмислити ситуацію, коли крізь психофрізичні стани сприйнята онтологічність Божого буття систематизується за супровідною участю метафрізичних проявів людської душі в контактах із Богом. Відтак віра уоднозначнює феномен першопочатку будь-яких інших станів порівняно зі станом сходження світлоносної сили в людську душу.

Філософсько-релігійний елемент непроявно вирізняється з двох міркувань: це - об'єктивізація уреальненої Богосвідомості ще за відсутності "вірувань" і непроявне утвердження феномену трансцендентно-іманентних станів як першоумови для усталення самих ідей через конкретику психофрізичних станів. Вияви феноменології віри здатні усистематизувати неоднозначну темпоритміку у (між)релігійних комунікаціях, у міждисциплінарнім просторі, а через обдумуваний "каскад" темпоритмік - супровідно долучатися до уреальнення ідеї Бога в структурі людини і світобудови.

За виниклих ситуацій ситуативно синхронізують свої прояви названі два методи в поєднанні із системним і герменевтичним. Прикметним $\epsilon$ тут розмисел Миколи Бердяєва. Він стверджував: "Не тільки Боги язичництва, а й Бог Старого Завіту ${ }^{6}$ страшний і грізний; $\mathrm{Biн}^{7}$ мстить і карає, Він не знає помилування, Він вимагає крові не тільки тварин, а й людей. Жах цей не був властивий природі Бога, а [-] природі людей..." [1, с. 322].

Тут феноменологізація Божества певною мірою контроверсує із традиційним текстовим тлумаченням Біблії, оскільки виникле тлумачення в одночассі ідентифікується із можливостями язичницьких богів. У цьому разі задля більшої повноти системний та герменевтичний методи спонукують з'ясувати, коли і за яких обставин законтактовують дві фрілософрсько-релігійні ідеї - тут обдумувана, а також ідея взаємодії добра-зла, світлатемряви. Однак у руслі феноменологізації віри заісновують не тільки відповідні зв'язки - водночас уможливлено переосмислити язичницьке в тому сенсі, як глибинніше розуміти складну й суперечливу темпоритміку всередині відношення "Бог-людина-Бог". 3 іншого боку, системний метод спонукує до пошуків, аби виявляти ситуативні місця для згармонізування.

Частково на таке прагнув відповісти Маркеллін Олесницький, коли стверджував: "I язичник, і тим паче фрілософ, котрий живе у християнськім періоді, має совість та моральну свідомість... Без богослов'я фрілософрія власними силами не в стані розв'язати питання про Абсолютне ${ }^{8} . . . "$ [9, с. 190]. У контексті обміркованої ідеї маємо два моменти: утвердження спільного для двох релігій - належного морального рівня, що стає підста-

\footnotetext{
6 Слова із цього текстового фрагмента, які написано з великої літери, в журнальній публікації подано з літери малої.

7 Тут і далі це слово у тексті Бердяєва - з малої літери.

8 у тексті М. Олесницького "Абсолютне" надруковано з малої літери.
}

вою розмірковувати без упереджень про Того, Хто Найвищий. Але коли в непроявно висловлених (між)релігійних комунікаціях помітна схильність шукати способи, як гармонійно сприймати Божество (і з позиції язичника, і з позиції тогочасної епохи автора), то при роздумах над конкретикою такого сприйняття сформувалася певна абсолютизація можливостей са́ме християнського богослов'я.

Ситуація стає закономірною, коли дослідник відходить від філософсько-релігійного мислення, а натомість у просторі його думок починає переважати консерватизм - одна з питомих рис богослов'я. Отже, елементи язичницького під час інтерпретації обміркованої ідеї в різний час неоднаково усталювались у спадщині українських мислителів. А намір згармонізувати неоднозначні ситуації уреальнюється через психокорекцію елементів антиномічного.

Отже, під час аналізу запропонованої ідеї доцільно максимально використати методологічні чинники, зважаючи на саму сутність Того, Хто Найвищий.

Ідеї одкровення, преображення (духовного просвітлення).

Продовжуючи розмірковувати про феноменологізаційні стани віри, треба зазначити: проявились вони i в названих тут ідеях. Так, зокрема, використавши системний та компаративний методи, Сергій Булгаков створює дискусійну ситуацію, коли добро-зло, світло-темрява як складові іншої (однойменної) ідеї нанизуються в аналізований простір: "У вірі не людина творить Бога, як каже невірство (Фейєрбах), а Бог відкривається людині, згодом і людина віднаходить себе у Бозі. Віра 3 об'єктивного боку є одкровенням" [2, с. 605].

Закономірно виникає контроверсія між темпоритмікою богословської думки й невірством (як деструктивним явищем). Неминучість такої контроверсії поєднано із максимально повним феноменологізаційним проявом віри - аж до її ототожнення з одкровенням. Що свідчить і про супровідний прояв поперемінно виражених трансцендентно-іманентних станів, які непроявно фоксує відношення "Бог-людина-Бог". Водночас феноменологізація віри на шляху до утвердження обміркованої ідеї пронизує гносеологічний простір сутнісно новими прикметами у вигляді релігійного знання. Такого знання, коли об'єктивізація змісту віри трансформується в повну достовірність [див.: 2, с. 613] як одну з необхідних умов знання (у традиційному розумінні на підставі логічних операцій). Але цього разу некласичність ситуації формує нові стани на підставі уже релігійної логіки.

До усталення цієї логіки ще раніше прилучився був Микола Бердяєв [1, с. 324], обґрунтовуючи ії перспективний розвиток, зокрема, - через фрактично виражений конструкт "віра-світове одкровення-язичництво". Автор непроявно розмірковує про історіософську доцільність багатовимірності самого поняття "світове одкровення", органічною частиною якого на певному етапі стало одкровення природи. Таким чином, логіка духовно-морального чинника необхідності взаємообумовлена логікою застосованого принципу поетапностіпослідовності.

Названі тут (з погляду релігійної логіки) два різновиди процесів розширив згодом Сергій Булгаков. Його методологічні рефлексії утверджувались на підставі часткової ситуативної сегментації двох фрілософськорелігійних ідей, а саме: обміркованої тут та ідеї взаємодії добра-зла, світла-правди. Застосувавши системний метод, дослідник класифікує одкровення як міжві- 
ровизнавче явище, апробуючи його сутність 3 погляду істини. Свої розмисли спрямовує в (між)релігійні комунікації, а відтак - і в міждисциплінарний простір (передусім - до психофізики, містики). Дослідник зазначав: "...види "одкровення", як і предмети його, можуть бути різними: і природні, і божественні, і демонічні...; воно може зіходити з різних світів та єрархій, отож саме́ по собі "одкровення"..., що розуміється як формально-гносеологічне поняття, може мати різний зміст... (адже ж і сатана набуває виду ангела світла), тому сам по собі "явний" або містичний характер цього вчення свідчить тільки про інтуїтивний спосіб його набуття, однак нічого не промовляє про його якість" [3, с. 733].

Філософрсько-релігійна спрямованість розмислів С. Булгакова проявляються в потребі психокорекції антиномічних станів і щодо виниклої нібито суперечності, як у понятті "одкровення" поєднати і божественне, і демонічне (але цього разу уже коли мовити про систематизацію названого поняття з погляду (не)істинності). Така спрямованість проглядається непроявно рівно ж у позиції, коли не гносеологія, не містика, а саме фрілософія релігії (у нашому випадку при усталенні обміркованої ідеї) спроможна обґрунтувати доречність класифікації одкровення С. Булгакова. Тобто мовиться про явище, повнота уреальнення якого в просторі антиномій сприймається закономірно, а відповідно й саму антиномію слід сприймати як незамінний функціональний чинник на шляху до з'ясування істини.

Ідеї одкровення, преображення (духовного просвітлення) осмислено в текстах і з погляду менталітету протоукраїнців-язичників, і в сприйнятті українців - сучасників С. Булгакова. Така позиція спонукала розрізнювати обмірковане поняття, унаслідок чого воно структурувалося в "одкровення свободи". Зокрема, у В. Зеньковського імпліцитно проглядається язичницьке через взаємодію елементів онтології та християнського богослов'я: "...не в одному тільки християнському світі лунає заклик до свободи. ...[Тому] одкровення свободи .... не пов'язується у свідомості з Іменем ${ }^{9}$ і справою Христа воно йде мовби знизу, із глибини людської природи, має "природний" характер" [5, с. 3].

Звідси випливає, що "природний" характер одкровення свободи проникає в простір одкровення природи, логічно набуваючи прикмет язичницького світу, котрий поєднується зі світом християнським саме з огляду на непроявно виражену українську традицію волелюбності й прагнення до свободи. I тому В. Зеньковський вирішальність в утвердженні названого характеру пов'язує передусім зі складною темпоритмікою усталення обміркованого одкровення свободи. Тобто такого явища "із глибини людської природи", де язичницьке хоч і виражене латентно, та все ж $є$ реально чинним для історичної пам'яті про одкровення як явище уже в просторі (між)релігійних комунікацій. Звідси випливає, що елементи язичницького в переосмисленій формі трансформуються в християнське буття задля повноти духовного буття українців - як етнонації. Тому дослідник закономірно стверджував: "...це [відношення свободи у Христі] $є$ попросту інший, благодатний порядок, який має лиш преобразити природню свободу, "виправдати" іï, дати їй розквітнути в її повноті й правді" [5, с. 8].

Феноменологізуючи обмірковані тут явища, автор "Свободи і соборності" в загальних рисах намагався з'ясувати маловивчену темпоритміку преображення-просвітлення в просторі (між)релігійних комунікацій. Він стверджував: "..."старозавітня людина"10, непреображена і непросвітлена, не тільки живе в нас, а й вступає в дуже складну й напружену боротьбу із "новим" у нас. У глибинах християнської душі два звучання заклику до свободи довго залишаються різними - тільки деякі світочі явили нам приклади такої внутрішньої цілісності, в якій усе природне вже просвітлене" [5, с. 3-4].

Однак далі промовистої констатації В. Зеньковський не пішов, оскільки цьому ситуативно завадили певні стереотипи у його мисленні - як представника християнського богослов'я. Адже системні іншовіровизнавчі привнесення, а відтак і переінакшення для будь-якої теології означали б початок її деструкції. 3 іншого боку, автор подав вартісне спостереження. Маємо на увазі те, що в (між)релігійних комунікаціях, коли й відбуваються неоднозначні стани в духовному оновленні, то вони темпоритмічно можуть бути виражені як цілісні усталення. 3 погляду "божественної діалектики" випливає, що суперечності у сфері духовного буття, які часто переходять в антиномії, стають закономірними етапами переосмислення "старого" в "нове", "язичницького" в "християнське". Через овірування - як безперервний багатовимірний духовний процес - з непроявною супровідністю зафункціоновує водночас і феноменологізація віри. Виникла гармонія, одначе, має свої межі, на формування яких впливають контроверзи. Існує своєрідна "зона безпеки": потрібний певний мінімум консервативного мислення, щоб відповідні галузі знання могли існувати (у цьому разі - назване богослов'я).

Осмислюючи ідеї одкровення, преображення (духовного оновлення), переконуємось, що вони тісно взаємообумовлюються, а їх темпоритмічні вираження в (між)релігійних комунікаціях і міждисциплінарному просторі зазнають структурних модифрікацій, ситуативно формуючи конструкт "одкровення природи - одкровення свободи".

\section{Висновки}

Методологічні рефлексії про обмірковані ідеї засвідчують, що:

1. Теоретичне осмислення теми $\epsilon$ першочерговим із кількох міркувань. Задля активізації евристичних зусиль щодо розробки, обґрунтування й упровадження в дослідницький процес нових термінів $€$ сенс безпосередньо поєднувати новоутворені поняття із тими, які належить відновлювати після вимушеної кількадесятирічної перерви.

2. Проблематично, аби поняття, котрих тривалий час не використовували ("містичний розум", "божественна діалектика", "релігійна логіка" та ін.), одразу гармонійно уконтекстовулися б у чинний процес. Однією 3 причин $€$ тут певна застереотипізованість стосовно самого їх сприйняття, що своєю чергою обумовлено маловивченістю питання на теоретичному рівні.

3. Комплексно формувати термінологічну структуру під час вивчення цієї теми означає системно з'ясовувати складні темпоритмічні ситуації, які об'єктивно існують між методами, принципами, відношеннями. Такий погляд сприяє розумінню суперечностей, парадоксів, зокрема, через феноменологізацію, унаслідок чого в проявах язичницького уможливлено гармонізувати неоднозначності.

4. Сприяливим тут є ускладнений багатовимірний "каскад" процесів із наразі маловивченою темпоритмізацією. Водночас є підстави розмірковувати про ці- 
лісність не тільки окремої фрілософсько-релігійної ідеї, а й про цілеспрямовану взаємопов'язаність обміркованих ідей. Чинниками, котрі сприяють цьому, $є$ історична й духовна пам'ять у взаємопов'язаності з (між)релігійними комунакаціями та міждисциплінарним простором.

5. Комплекс виниклих ситуацій уперспективнює поглиблене розуміння взаємозв'язків названих видів пам'яті з ретроспекцією на простір менталітетних особливостей, щоб усвідомлювати очевидне: язичницьке (уже в охристиянізованому вигляді) стає органічною складовою сучасної культури українців як етнонації.

\section{ЛІТЕРАТУРА}

1. Бердяев Николай. Происхождение зла и смысла в истории / Николай Бердяев // Вопросы Философии и Психологии [Москва]. - 1908. - Сент.-окт. - Кн. 4 (94). - С. 287-334.

2. Булгаков Сергей. Трансцендентальная проблема религии / Сергей Булгаков // Вопросы Философии и Психологии [Москва]. - 1914. - Кн. 4 (124). - Сент.-окт. - С. 580-652.

3. Булгаков Сергей. Трансцендентальная проблема религии. (Продолжение) / Сергей Булгаков // Вопросы Философии и Психологии [Москва]. - 1914. - Нояб.-дек. - Кн. 5 (125). - C. $728-780$.

4. [ґоґоцький Сильвестр]. Философский лексикон / [Сильвестр Ґоґоцький]. - К. : В Университетской типографии, 1872. - Т. 4: П.Р.С. - Вып. 1. - III с.+ 472 с. - (На титульному аркуші $є$ "С. Г." - криптонім автора).
5. Зеньковский В. Свобода и соборность / В. Зеньковский // Путь [Париж]. - 1927. - № 7. - Апр. - С. 3-22.

6. Зеньковский В. В. [Рец. на кн.]: Wilfred Monod. Du protestantisme. - (Серія "Les religions". Felix Alcan, 1928) / В. В. Зеньковский // Путь [Париж]. - 1928. - № 15. - Февр. - С. 135-137.

7. Зеньковский В. В. Основы христианской философии / В. В. Зеньковский. - М. : Канон+, 1997. - 560 с. - (История христианской мысли в памятниках)

8. Марцінковська Дарина. Філософський та богословсько-релігієзнавчий досвід інтерпретації проблем кредології / Дарина Марцінковська // Вісник Прикарпатського національного університету. Філософські та психологічні науки. - ІваноФранківськ : ДВНЗ "Прикарпатський національний університет ім. Василя Стефаника", 2015. - Вип. 19. - С. 96-103.

9. Олесницкий М. А. Из системы нравственного богословия / М. А. Олесницький // Труды Киевской Духовной Академии. - 1888. - № 2. - С. 163-205.

10. Печеранський І. П. Зв'язок політичної фрілософрії та ідеології в контексті українського консерватизму / І. П. Печеранський // Гілея: науковий вісник. Збірник наукових праць / [гол. ред. В. М. Вашкевич]. - К. : Гілея, 2016. - Вип. 113 (10). C. $285-290$

11. Преображенський С. І. Позахристиянські компоненти в свідомості православного віруючого: український контекст : автореф. дис. на здобуття наук. ступеня канд. філос. наук : спец. 09.00.11 "Релігієзнавство" / Степан Іванович Преображенський ; НАН України. Ін-т фрілософії ім. Г. С. Сковороди. - К. : [б. в.], 2010. - 20 c.

Тимэнык Зиновий,

кандидат философских наук, доцент кафедры истории Украины и этнокоммуникации, Национальный университет "Львовськая политехника", г. Львов

\section{ИНТЕРПРЕТАЦИЯ ЯЗЫЧЕСКОГО В ФИЛОСОФСКО-РЕЛИГИОЗНЫХ ИДЕЯХ УКРАИНСКИХ МЫСЛИТЕЛЕЙ (70-е г2. ХІХ $\mathrm{cm}$ - - 60-е г2. ХХ cm.): МЕТОДОЛОГИЧЕСКИЕ РЕФЛЕКСИИ}

На основании наследия украинских философов этого периода роль языческого освещена в контексте идеи Бога в структуре человека, миростроения и идей откровения, преображения (духовного обновления). Особенностью методологических размышлений есть высказывания о разных проявлених темпоритмики. Автор обосновывает объективную взаимосвязь и гармоничность этих идей.

Ключевые слова: "божественная диалектика"; "мистический разум"; "откровеноведение"; "религиозная логика"; темпоритмика.

Timenyk Zynovij, Ph.D. in Philosophy, Associate Professor of the Department of History of Ukraine and Etnical communications, National University "Lviv Polytechnics"

\section{THE INTERPRETATION OF PAGANISH IN THE PHILOSOPHICAL AND RELIGIOUS IDEAS OF UKRAINIAN PHILOSOPHERS OF 1870s-1960s: METHODOLOGICAL REFLECTIONS}

The object for analysis is the philosophical and theological idea of God in the structure of human, the universe and His names. The ideas of transfiguration and revelation (spiritual renewal) have also been discussed. Interpretation of paganism is based on legacy of Ukrainian thinkers (1870s-1960s), including but not limited to Sylvestr Gogotskyi, Markellin Olesnytskyi, Mykola Berdiaiev, Serhii Bulhakov, and Vasyl Zinkivskyi.

The use of different methods - functional, systemic, comparative, and hermeneutic, helped conduct a comprehensive analysis of the topic in view of different temporhythmical interconnection of (inter)religious communications and interdisciplinary space. A claim is made that the contradictions, which can become antinomies, are regular as they stimulate the search for truth through revealing truthfulness when expressing the ideas discussed.

A complex of processes that have emerged forms their so called "cascade" in which certain paradoxicality is

СХІД № 1 (147) січень-лютий 2017 р. 
caused by such term phrases as "mystical sense", "divine dialectics", "religious logics". Yet, the use of principles of integrity, free development and spiritual change, transcendence and harmony-symphony gives ground for substantiating their relevant use in modern science after decades of forced suppression. Simultaneously, new (author's) terms are put forward: "multiprocess simultaneity", "believe-in", "revelation studies". In this way a lacuna of necessary terms may be filled to a certain extent which will encourage diversification of heuristic activity and completeness of the analysis itself. Attention was also given to the connection between ideas analyzed and certain mentality features of Ukrainians, particularly within the context of "freedom revelation". One of the factors for direct functional contextual appropriation of the author's terms is systemic understanding of faith phenomenologization and a comprehensive analysis of the relation "God-human-God" which is multidimensional in its structure.

Objective regularity of interconnection between ideas analyzed is affirmed. Elements of synthesis are formed in their space and as a matter of course they harmonize and sometimes transform into the state of symphony.

Key words: "divine dialectics"; "mystical sense"; "religious logics"; temporal rhythm.

\section{REFERENCES}

1. Berdiaiev, N. (1908), Origin of evil and sense in the history, in: Voprosy Filosofii i Psikhologii, Semtember-October, book 4 (94), Moscow, pp. 287-334. (rus).

2. Bulhakov, S. (1914), Transcendental Problem of Religion, in: Voprosy Filosofii i Psikhologii, September-October, book 4 (124), Moscow, pp. 580-652 (rus).

3. Bulhakov, S. (1914), Transcendental Problem of Religion, in: Voprosy Filosofii i Psikhologii, November-December, book 5 (125), Moscow, pp. 728-780 (rus).

4. [Gogotskyi, S.] (1872), Philosophical Lexicon, vol. 4: P.R.S., V Universitetskoi Tipografii, Kyiv, II p.+579 p.+IV p. (rus).

5. Zienkovskii, V. (1927), Freedom and Sovereignty, in: Put, April, book 7, Paris, pp. 3-22 (rus).

6. Zienkovskii, V. (1928), [Reviev of the book] : Wilfred Monod. Du protestantisme. (Series "Les religions". Felix Alcan, 1928), in: Put, February, book 15, Paris, pp. 135-137 (rus)

7. Zienkovskii, V. (1997), The Foundations of Christian Philosophy, Kanon+, Moscow, 560 p. (rus).

8. Martcinkovska, D. (2015), Philosophical, theological and religious exspirience of the interpretation of credology's problems, in: Visnyk Prykarpatskoho Universytetu. Filosofski i psycholohichni nauky, iss. 19, Ivano-Frankivsk, pp. 96-103 (ukr).

9. Oliesnitckii, M. A. (1888), From the system of moral theology, in: Trudy Kiievskoi Dukhovnoi Akadiemii, book 2, Kyiv, pp. 163-205 (rus)

10. Pecheranskyi, I. (2016), The connection between political philosophy and ideology in the contex of Ukrainian conservatism, in: Hileia, iss. 113(10), Kyiv, pp. 285-290 (ukr).

11. Preobrazhenskyi, S. (2010), Out of Christian components in the consiousness of the Ortodox believer: autoref. of the dissertation for the degree of Doctor of Thilosophy in the specialization 09.00.11 "Religious studies", Kyiv, 20 p. (ukr).

() Тіменик Зиновій

Надійшла до редакції 28.01.2017 